\title{
Effects of Principal Leadership, School Climate and Teacher Achievement Motivation to Teachers Work Commitment
}

\author{
Yulia Hafni \\ Educational Administration \\ Department, Post Graduate Program \\ Universitas Negeri Medan \\ Medan, Indonesia \\ Coresponding email : \\ yulia.hafni@gmail.com
}

\author{
Darwin \\ The Lecturer of Universitas Negeri \\ Medan \\ Medan, Indonesia \\ Coresponding email : \\ darwin.dbep@gmail.com
}

\author{
Zulkifli Matondang \\ The Lecturer of Universitas Negeri \\ Medan \\ Medan, Indonesia \\ Coresponding email \\ :zulkiflimato@gmail.com
}

\begin{abstract}
The study aims to determine the effect of Principal Leadership on Achievement Motivation, the influence of School Climate on Achievement Motivation, the influence of Principal Leadership on Teacher Work Commitment, the influence of School Climate on Teacher Work Commitment, and the effect of Achievement Motivation on Teacher Work Commitment. This research was conducted in 2019 to SMP Negeri teachers in Tanjung Morawa sub-district, with a population of 235 teachers. The number of samples determined by Slovin formula obtained 148 teachers, taken with the Proportional Random Sampling technique. Data collection was carried out using a questionnaire after being trialed. Validity Test is done by Product Moment Correlation and Reliability test using Cronbach's Alpha coefficient. Data analysis techniques used are descriptive analysis, test requirements analysis, and hypothesis testing using path analysis. Research findings that Principal Leadership has a direct positive effect on Achievement Motivation, School Climate has a direct positive effect on Achievement Motivation, Principal Leadership has a direct positive effect on Teacher Work Commitment, School Climate has a positive direct effect on Teacher Work Commitment and Achievement Motivation has a direct effect on Work Commitment Teacher. To increase the Commitment of Teacher Work can be done by increasing the Principal's Leadership, School Climate and Teacher Achievement Motivation.
\end{abstract}

Keywords- Principal Leadership; School Climate; Achievement Motivation; Work Commitment

\section{INTRODUCTION}

Commitment is a form of dedication or obligation that binds someone to another person, a certain thing, or a certain action. Commitments can be voluntary or forced, depending on each situation. Some people commit to something because they love what they do. Some other people commit because they feel afraid of losing when they don't live up to that commitment. Others may commit because they feel they have the responsibility to do it. In school organizations a teacher also has a commitment, [1] author describes work commitment as another term of organizational commitment. According to him, organizational commitment is an important behavioral dimension that can be used to assess employee's tendency to stay as a member of an organization. Organizational commitment is an identification of someone's involvement that is relatively strong towards the organization. Organizational commitment is the desire of members of the organization to maintain their membership in the organization and be willing to work hard for the achievement of organizational goals.

The teacher's work commitment delivered from some of the opinions above can be concluded that the teacher's work commitment is a form of high concern from a teacher for the work given to him and a high sense of acceptance of the organization and has a strong desire to remain part of the organization. Committed teachers have an attachment to duties and obligations as a teacher who can give birth to responsive and innovative responsibilities and attitudes towards the development of science and technology. So in this commitment there are several elements, among others, there is the ability to understand themselves and their duties, emanating inner attitude (inner strength) external strength and responsiveness to change. These elements give birth to responsibilities towards duties and obligations that become a person's commitment so that the task is carried out with full sincerity. The teacher's responsibility is very large between his role as an educator and a teacher. As a teacher a teacher must make plans, implementations, and assessments and follow up in the learning process. Whereas as an educator, the teacher is in charge of forming the attitude, mentality and character of the students towards better, all of that will not be realized if there is no high work commitment from the teacher's person.

The role of teachers in Law Number 14 of 2005 concerning teachers and lecturers Article 1 is stated as follows "Teachers are professional educators with the main task of educating, teaching, guiding, directing, training, evaluating, and evaluating students in early childhood education in the education pathway. Formaly, basic education and secondary 
education".Teachers as education implementers play an important and strategic role in determining the achievement of learning objectives. The negative impacts caused by teachers who are not committed are: (1) teachers do not work seriously, (2) teachers do not provide the best service, (3) teacher work responsibilities are low, (4) teacher discipline levels are low, and (5) the desire for achievement and self-development of teachers is still low. While the positive impact of teachers who have commitment are: (1) working earnestly, (2) being proud as a teaching profession, (3) proactively improving themselves in accordance with the vision, mission and goals of the school, (4) always maintaining the good name of the teacher, and (5) provide the best service to students.

In fact, there are still many teachers who are faced with the problem of low work commitment, so that they are not really serious in carrying out their duties which causes the quality of education is low. Specifically, the Head of the North Sumatra Province Education Office [2] suggests that based on the achievement index issued by the Ministry of Education and Culture is a material for reflection for stakeholders, so teachers and principals must focus on improving the quality of education.

Observations made by researchers by interviewing several teachers, from 13 teachers, researchers found that 10 of the 13 teachers interviewed expressed their reluctance to be actively involved in activities in school.Some factors that affect teacher work commitments based on facts in the field are equivalent to the opinions of experts, According [3], that one's work commitment is influenced by several factors such as motivation, compensation, training, leader function, climate of cooperation, work spirit and conflict that occurs in an office. Author [5] says that teacher commitment, besides growing from within each, is also influenced by the principal as an element of leadership.Furthermore [6] argues that achievement motivation is one of the factors that influence organizational commitment.

\section{LITERATURE REVIEW}

\section{A. Teacher's Work Commitment}

Commitment is an action you take to support a particular choice of action, so that the choice of that action can be carried out steadily and wholeheartedly. Kanter in [7] also suggests three forms of teacher/organizational work commitment, including:

- Continuous commitment (commitment), which is a commitment related to the dedication of teachers in carrying out the life of school organizations and producing people who are willing to sacrifice and invest in school organizations.

- Integrated commitment (cohesion commitment), namely the commitment of teachers to school organizations as a result of social relations with other members within the school organization. This happens because the teacher believes that the norms adopted by the organization are beneficial norms.
- Controlled commitment, namely the commitment of teachers to the norms of school organizations that provide behavior in the direction they want.

\section{B. Principal's Leadership}

The term leadership is interpreted variously, depending on the point of view and the context of understanding of the experts who discuss it. Leadership is essentially the science and art of influencing and mobilizing others by building obedience, loyalty, trust, respect and cooperating passionately to achieve the expected goals. Principal's leadership is measured through the following indicators: Charisma, Individual Sensitivity, Intellectual Stimulation, and Inspiration.

\section{School Climate.}

School climate is something that must be considered by the principal in order to improve the quality of education. A conducive school climate is expected to support an effective learning process, so that all school members feel comfortable in it. A conducive school climate will arouse enthusiasm for learning and awaken the potential of learners so that they can develop optimally. The indicators are: Physical environment; Social environment; Effective environment; Academic environment

\section{Teachers Achievement Motivation}

According to [5] motivation is a strength both from within and from outside that drives a person to achieve certain goals that have been set previously. In addition to that, according to [7] statement one of the characteristics of achievement motivation is that those needs can be learned. Previously low achievement motivation, after receiving training and experience increased. Based on the explanation of this mindset, this research can be described in Figure. 1 below:

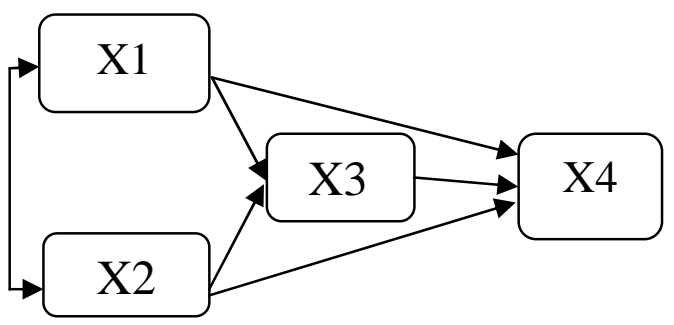

Fig. 1. Research Paradigm influence between variables

$\begin{array}{ll}\text { Exp } & \\ \text { X1 } & \text { : Principal's leadership } \\ \text { X2 } & \text { : School Climate } \\ \text { X3 } & \text { : Teacher achievement motivation } \\ \text { X4 } & \text { : Teacher's Commitment }\end{array}$

\section{METHODOLOGY}

To determine the number of samples in this study Slovin formula was written by [9] namely:

$$
\mathrm{n}=\frac{N}{N, d^{2}+1}
$$


The method in this research is a quantitative method with descriptive research type. This method has the aim to describe five things, namely: (1) The influence of the principal's leadership on teacher achievement motivation, (2) The effect of the school climate on teacher achievement motivation, (3) The effect of the principal's leadership on teacher work commitments, (4) The influence of school climate on teacher work commitments, (5) The effect of teacher achievement motivation on teacher work commitments.To test the instrument is valid or invalid, then the construction validity test is done by factor analysis, which corrects the score of the item using the Pearson Product Monent formula, namely:

$$
r_{x y}=\frac{N(\Sigma X Y)-(\Sigma X)\left(\sum Y\right)}{\sqrt{\left(N \cdot \Sigma^{Y^{2}}-(\Sigma Y)^{2}\right\}\left(N \cdot \Sigma X^{2}-(\Sigma X)^{2}\right)}}
$$

\section{RESULT AND DISCUSSION}

The results of descriptive analysis of the variables of Principal Leadership (X1), School Climate (X2) and Achievement Motivation (X3) to the teacher's work commitment (X4) to 148 respondents are presented in the summary in Table 1 below.

TABLE 1. SUMMARY OF RESULTS OF DESCRIPTIVE ANALYSIS OF RESEARCH VARIABLES

\begin{tabular}{|l|l|l|l|}
\hline \multicolumn{1}{|c|}{ X1 } & \multicolumn{1}{c|}{ X2 } & \multicolumn{1}{c|}{ X3 } & \multicolumn{1}{c|}{ X4 } \\
\hline 148 & 148 & 148 & 148 \\
\hline 104.25 & 98.99 & 98.89 & 103.93 \\
\hline 102.00 & 98.00 & 99.00 & 104.00 \\
\hline 102 & 98 & 99 & 104 \\
\hline 14.250 & 15.758 & 14.916 & 14.455 \\
\hline 203.073 & 248.306 & 222.497 & 208.934 \\
\hline 63 & 74 & 67 & 65 \\
\hline 75 & 62 & 65 & 70 \\
\hline 138 & 136 & 132 & 135 \\
\hline 15429 & 14651 & 14635 & 15382 \\
\hline
\end{tabular}

TABLE 2. SUMMARY OF TEST NORMALITY IN RESEARCH DATA

\begin{tabular}{|c|c|c|c|c|c|}
\hline & $\mathrm{X}_{1}$ & $\mathrm{X}_{2}$ & $\mathrm{X}_{3}$ & $\mathrm{X}_{4}$ \\
\hline \multicolumn{2}{|l|}{$\mathrm{N}$} & 148 & 148 & 148 & 148 \\
\hline \multirow{2}{*}{$\begin{array}{l}\text { Normal } \\
\text { Parameters }^{\mathrm{a}, \mathrm{b}}\end{array}$} & Mean & 104.25 & 98.99 & 98.89 & 103.93 \\
\hline & $\begin{array}{l}\text { Std. } \\
\text { Deviation }\end{array}$ & 14.250 & 15.758 & 14.916 & 14.455 \\
\hline \multirow{3}{*}{$\begin{array}{l}\text { Most } \\
\text { Extreme } \\
\text { Differences }\end{array}$} & Absolute & .097 & .078 & .092 & .059 \\
\hline & Positive & .097 & .078 & .092 & .059 \\
\hline & Negative & -.059 & -.055 & -.065 & -.050 \\
\hline \multicolumn{2}{|c|}{ Kolmogorov-Smirnov Z } & 1.174 & .945 & 1.117 & .720 \\
\hline \multicolumn{2}{|c|}{ Asymp. Sig. (2-tailed) } & .127 & .333 & .165 & .677 \\
\hline
\end{tabular}

Based on the price of the path coefficient obtained from the calculation results, can be drawn a path diagram (Path Diagram) research variables as in Figure 2 below.

$\mathrm{e}_{1}=0,813$

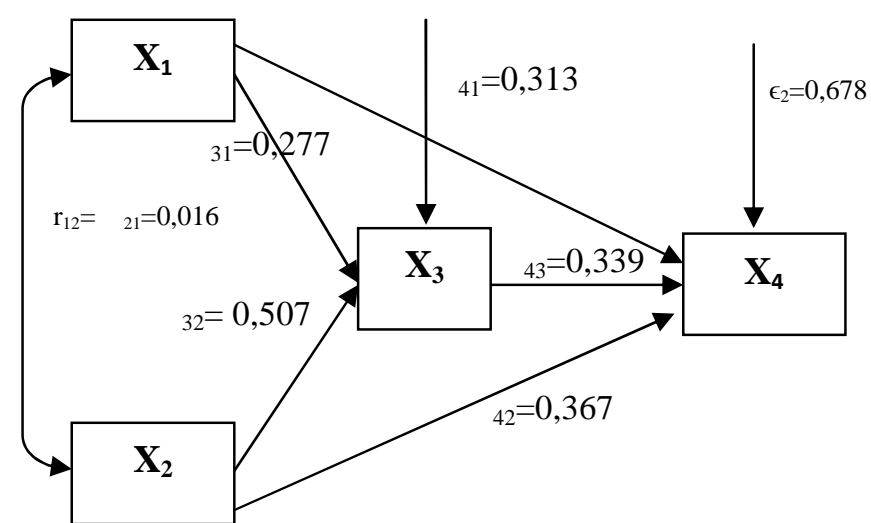

Fig. 2. Empirical Causal Relations of X1, X2, X3, to X4.

Next, a summary of the direct and indirect effects of Principal Leadership (X1), School Climate (X2) and Achievement Motivation (X3) on the Teacher's Work Commitment (X4) is presented in Table 3.

TABLE 3. SUMMARY OF DIRECT AND INDIRECT EFFECTS OF RESEARCH VARIABLES

\begin{tabular}{|c|c|c|c|c|c|}
\hline \multirow{3}{*}{$\begin{array}{l}\text { Vari } \\
\text { ables }\end{array}$} & \multicolumn{4}{|c|}{ Effect } & \multirow{3}{*}{$\begin{array}{c}\text { Total } \\
\text { Influence }\end{array}$} \\
\hline & \multirow[t]{2}{*}{$\begin{array}{c}\text { Direct } \\
\mathrm{X}_{4}\end{array}$} & \multicolumn{3}{|c|}{$\begin{array}{l}\text { Indirect results from the } \\
\text { multiplication of the direct path } \\
\text { coefficient with the correlation } \\
\text { coefficient of exogenous variables }\end{array}$} & \\
\hline & & $X_{1}$ & $\mathrm{X}_{2}$ & $\mathrm{X}_{3}$ & \\
\hline $\mathrm{X}_{1}$ & 0,098 & - & 0,002 & 0,030 & 0,130 \\
\hline $\mathrm{X}_{2}$ & 0,115 & 0,002 & - & 0,064 & 0,181 \\
\hline$X_{3}$ & 0,135 & 0,030 & 0,064 & - & 0,229 \\
\hline \multicolumn{5}{|l|}{ Total } & 0,540 \\
\hline
\end{tabular}

\section{CONCLUSION}

\section{A. Conclusion}

The results of the study concluded that there was a positive direct effect on Principal Leadership, School Climate and Achievement Motivation on the Work Commitment of Junior High School Teachers in Tanjung Morawa. Thus, it can be stated to improve the Teacher's Work Commitment can be done by increasing the Principal's Leadership, increasing the School's climate more conducive and increasing Teacher's Achievement Motivation.

\section{B. Recommendation}

Based on the research findings it is recommended: For the School Principal as information to be able to improve the Teacher's Work Commitment by involving teachers in making decisions at the School, providing opportunities for continuing education, following training in improving teacher competency. For the teacher as a material for self-reflection to be able to improve the quality of themselves and their competencies in order to increase their commitment.

For further researchers, as a comparison material for relevant research in the future to be able to conduct research with a larger sample size and other variables that affect Work Commitment. 


\section{REFERENCES}

[1] Colquit, Jason A., Jeffery A. LePine., dan Michael J. Wesson, 2009. Organizational Behavior: Improving Performance and Commitment in the Workplace. New York: McGraw-Hill Companies.

[2] Luthans, Freed. 2005. Perilaku Organisasi, Edisi kesepuluh. Diterjemahkan oleh Vivin A.Y. Yogyakarta: Andi Offset.

[43] Mowday, Porter \& Steers. (1982). Employee Organization Lngkages: the Psikology Commitment, Absenttees in and Turnover. New York: Academi Press

[4] Robbins, Stephen, P. 2006. Perilaku Organisasi. Diterjrmahkan oleh Benyamin Molan. Jakarta: Indeks.

[5] Sehertian A.Piet. 2000. Konsep Dasar Dan Teknik Supervisi Pendidikan Dalam Rangka Pengembangan Sumber Daya Manusia. Jakarta: Rineka Cipta.

[6] Usman, Husaini, 2008. Manajemen. Teori Praktik \& Riset Pendidikan, Jakarta: Bumi Aksara.

[7] Syamsiah. 2013. 'Pengaruh Budaya Organisasi, Motivai dan Kompetensi terhadap Komitmen Guru SMP Negeri 17 Semarang' Tesis. Semarang: Universitas Negeri Semarang.

[8] Taruna Dwidjajaadi. Pengaruh Gaya Kepemimpinan, Motivasi Kerja, Lingkungan Fisik dan Teknologi terhadap Keefektifan Organisasi di Direktorat Jenderal Anggaran Departemen Keuangan RI. Sinopsis Disertasi (Jakarta: Program Pascasarjana Universitas Negeri Jakarta, 2008), p. 16 